\title{
THE RELIGION OF TRAGEDY AND THE CHRIST-
}

\section{IDEAL.}

RAGEDY (which literally translated means "goatin which a male-goat was offered to Dionysus. Arriving from abroad the god used to enter with his followers in festive processions. He was accompanied by Silenus, the lover of the cup, by fauns and bacchantes raving like maniacs in exuberance of life. The ass appeared in the procession, carrying a shrine or Silenus or the god himself. Wherever the procession went, there was great rejoicing, for Dionysus spread life, joy, liberty, rapture and drunkenness.

In the Dionysian festival the adventures of the god are imitated. Having undergone suffering and death he has been born again and now he comes as a liberator and saviour. He offers himself as the exhilarating drink and is the martyr of his divinity. $\mathrm{He}$, the offspring of the vine, passes through his first life as the grape. $\mathrm{He}$ is cruelly tortured and mangled in the wine-press; his blood is shed, and he passes through a process of fermentation to rise from the tomb again as the intoxicating drink of the vine.

The myth tells us that he was the son of Zeus and Semele, but that before his birth Hera, the wife of Zeus, induced Semele to demand that her lover should show himself to her in all his divinity. Since, however, as also 
in the case of the Jewish Yahveh, no one could see God and live (Ex. xxxiii. 20) Semele died at the sight of this theophany and Zeus transferred the unborn babe to his thigh where it grew to full babyhood and was then born a second time; hence the child was called Dithyrambos, i. e., "he of two doors," the twice born, and the irregular meter of poetry celebrating his birth is called after him the dithyrambic measure.

Intoxication is here not regarded as a loss of selfcontrol, but as divine obsession. The god himself is assumed to speak out of the mouth of the one who is drunk, who is inspired. Liberated from the bondage of flesh, of sorrow, and of all evil, he enters into a state of ecstacy and enjoys the bliss of divinity, of liberty, of pure spirituality.

Connected with the worship of Dionysus were the socalled mysteries, dramatic performances representing the destiny of the god, his passion, his death, his resurrection, ending in his triumphal entry into the homes and hearts of the people.

Orphic and other mysteries are parallel formations, and it appears that all of them were imported from the East, although we may be sure that mysteries, or, generally speaking, half dramatic performances and dances of a symbolic nature, were common to all people all over the earth at a certain period of their development. They existed not only in ancient Egypt, Babylonia, Phenicia and Greece, but also in Tibet, in Africa and even among the North American Indians. Under the symbolism of certain acts the initiated persons were taught in the mysteries certain religious doctrines such as the eternal reappearance of life and the immortality of the soul.

The priesthood of the old established gods of Greece may originally have been hostile or perhaps indifferent to the new movement of Dionysian mysteries, but the new 
ideas were too powerful and became too popular to be ignored. It appears that the Eumolpids, the ancient priestly family of Athens, deemed it wise to incorporate the new methods in their own system of the Demeter cult, the worship of the earth-mother, and celebrated in annual repetition the Eleusinian mysteries in which the descent of Persephone to Hades was symbolized in a dramatic performance. The daughter of the earth-goddess, the maiden representing vegetation, dies annually in the fall and comes to life again in spring. The acts of the drama deal with the rape of Persephone, the search for her by the disconsolate mother and her friends, the instalment of Persephone as queen in the realm of the dead and her annual return in spring with the bloom of flowers as well as the fruit of the fields. The course of nature symbolizes man's destiny. To set forth the continuity of life a torch was handed from hand to hand, and the ear of wheat, the seed of future life, was worn by the initiates as an emblem of immortality.

We need not doubt that the performance of the fate of Osiris in the Egyptian ritual was kin in spirit, expressing the same idea. Osiris lived on earth as a benefactor of mankind, a lawgiver, as the inventor of agriculture, of writing, of science, of laws and the social order as well as of civilization in general. Egyptian religion knows of his death and his descent into the underworld where he becomes the judge of the dead endowed with the power to give to those who have obeyed his commandments a life of bliss in the fields of Aalu, the Greek Elysium.

Orpheus, the Thracian singer, was another figure in the mystery religions. We know that he lost his beloved wife Eurydice and followed her into the nether world where with his sweet song he touched the heart of the stern Hades. Hermes, the leader of souls, accompanied the faithful lovers back to life, but Orpheus could not re- 
strain himself and, contrary to the dictates of the law in the land of death, he turned to behold his bride, and she disappeared. The details of the mystery performance are lost to us; we only know that Orpheus sings to the lyre, that the whole creation, especially wild animals, come to listen to his enchanting strains and that he is killed and torn to pieces by his own worshipers, by the mænads who rove with him through the mountains.

All these mysteries, these dramatic presentations of the destinies of suffering gods who offer up their lives for the good of mankind, are tragedies, and comparative religion on the basis of anthropological research among savage races has discovered that they are a modified form of prior human sacrifices. It was the god's death that was enacted, and it was the god himself, his incarnation, his representative on earth, the high-priest of the tribe or the king himself, who was originally offered as the victim, as the hostia, and eaten. We live by eating the god of life, by nourishing ourselves with bread, the fruit of the fields, and by drinking the blood of the grape, and in the days of savagery it was deemed necessary to perform the act in all its cruel barbarity for the sake of perpetuating this divine munificence.

In the progress of civilization human sacrifices were abolished, and the sacred animal of the god was accepted as a fit substitute in the story of Abraham who offers a ram in the place of his son, Isaac. The symbol replaced the actual deed just as the hungry souls, originally fed with real food, had to be satisfied with the viands painted on the walls of their tombs (as instanced in the chambers of the dead of ancient Egypt); and while originally a master's slaves were killed to serve him in the other world, in a more cultured age a number of figurines (the ushabtiu of the Egyptians) were placed in his grave to serve the same purpose. 
Is there any need of asking the question, why this idea of the suffering god, his death and resurrection, is so common all over the world and among so many nations? It is obvious that this doctrine symbolizes a great truth. It is undeniable that the maintenance of life and its renewal become possible only by constant sacrifice, and the heroes of mankind are martyrs whose struggles and whose passion are the condition of a victory over evil, of the attainment of prosperity, of life and of liberty. Such has been the religion of mankind, such is the fundamental idea in the Christian faith, and such will remain the religious ideal of the future.

The kinship between the old mystery religions and Christianity was recognized by the early Christians who pictured Christ as Orpheus in the Catacombs at Rome.

We need no longer wonder that Christianity spread over the world like a wildfire on the prairie after a drought. The nations were prepared for it. Indeed they had been believing in religions which had been born of the same spirit and were based upon the conception of life as a tragedy. The grotesque mythologies of the old gods were no longer acceptable to the more civilized age, while the story of the tragedy of Golgotha was more human, and therefore more humane, although the underlying truth was not different.

The formation of the Christian doctrines is by no means an accident. The life of Jesus (if he was, as we need not doubt, a real personality) was read in the spirit of these traditions, and the old pagan beliefs were superadded upon the story of the carpenter's son of Capernaum. Hence it is easy to point out the traces of myth and legend in the Gospels and there is no doubt that the saviour ideal existed before Jesus. It existed long before the origin of Christianity, not among the Jews alone, but among all the races of mankind; and this saviour ideal assumed a new form 
after the breakdown of paganism in the new religion of Christianity.

In Christianity the belief in a saviour was reestablished in a new and purified faith. The saviours of the pagans were heroes, sons of Zeus or other gods, they were gods walking on earth, they were fighters with a club or sickle sword, but Jesus is a spiritual hero, the teacher, the healer, the benefactor of mankind, conqueror of death and saviour, the martyr who gives himself up in vicarious atonement, who dies and rises from the grave to give life eternal to all who believe in him.

In this sense Augustine is perfectly right when he claims that Christianity is not a new-fangled religion but existed from the beginning under other names. He goes as far as to declare that pileatus (i. e., the cap-wearer, Mithras) is but another name for Christ, and so are all the pagan saviours, Esculapius and Dionysus, Orpheus, the ancient Baal of Tyre and Bel Marduk, Osiris and even the American Hiawatha-all are parallel formations of the Christ of Christianity.

It is wrong to speak (as does Schiller) of "the plaesure" we take in seeing tragic subjects on the stage. We ought not to use the word "pleasure," we ought rather to speak of the "satisfaction" which it affords to the spectators to witness a tragedy. It is not pleasure in the common sense of the word; it is the satisfaction of an intensely spiritual want, and this want is of a religious nature. Schiller means "satisfaction" and proves in his poetical compositions that he understood the problem in spite of the misnomer of his explanation.

Prof. Calvin Thomas, on another page of this number of The Monist, rightly calls attention to the fact that in a more primitive state of culture man not only took delight in the performance of tragedies on the stage, but rejoiced in witnessing the infliction of actual torture in the ritual of 
sacrifices; and we must bear in mind that the goat is a mere substitute for a human Dionysus, as much as the bull, the ram, the boar and other sacrificial animals symbolize the gods whose emblems they are. The Indians were proud of the prowess displayed by the victims of the sun-dance; they claimed that the Great Spirit too looked down upon them with admiration and was pleased that his children could stand such torture without wincing.

All true art is of a religious nature; so above all is the drama, and the highest drama will always remain the tragedy. It will always represent the destiny of the man who walks on the heights of life, who becomes implicated in evil, struggles, suffers and is defeated, yet in spite of his defeat his ideal conquers. Struggle, death and resurrection or apotheosis are the essential elements of the tragedy, not in the literal but in the symbolical meaning of these words, in the sense that every man constantly and unavoidably experiences these phases in his spiritual growth.

Art represents life, and every piece of art reflects a world-conception, a philosophy, a religious conviction. Since struggle, death, and a renewal of life on a higher plane are the characteristic features of life, a truly thoughtful man will naturally find a satisfaction in witnessing the performance of a tragedy.

Suffering has been a part of religious ceremonies the world over, and it is only within historical times that civilized governments have suppressed rituals of this kind. Among savage races Miss Alice $C$. Fletcher was present at the last performance of the sun-dance ritual among the Indians, and her detailed report can be seen in the Smithsonian Reports.

From time immemorial the Khonds, a Dravidian race in the interior of India, in Bengal and Madras, have offered, often annually, in some districts every third year, human sacrifices to the earth goddess, called Zakaree- 
Pennu, or Tari-Pennu, or Bera-Pennu, or Thadha-Pennu. The victim called meriah had to be purchased, unless he was born a meriah, by being the child of a former victim, or had in childhood been devoted to this sad fate by his father or guardian.

The details of the sacrifice differed in different districts, but everywhere the victim was cut to pieces, and the slices were mixed with the seed grain or buried in the soil of the different fields. There are quite a goodly number of various descriptions extant. We quote Mr. Russell's report on the districts under his control of the year $1837:^{1}$

"The ceremonies attending the barbarous rite [Khond human sacrifice] vary in different parts of the country. In the Māliahs of Goomsur, the sacrifice is offered annually to Thadha Pennu, under the effigy of a bird intended to represent a peacock, with the view of propitiating the deity to grant favorable seasons and crops. The ceremony is performed at the expense of, and in rotation, by certain mootahs [districts] composing a community, and connected together from local circumstances. Besides these periodical sacrifices, others are made by single mootahs, and even by individuals, to avert any threatening calamity from sickness, murrain, or other causes. Grown men are the most esteemed [as victims], because the most costly. Children are purchased and reared for years with the family of the person who ultimately devotes them to a cruel death, when circumstances are supposed to demand a sacrifice at his hands. They seem to be treated with kindness, and, if young, are kept under no constraint; but when old enough to be sensible of the fate that awaits them, they are placed in fetters, and guarded. Most of those who were rescued had been sold by their parents or nearest relations, a practice which, from all we could learn, is very common. 201.

${ }^{1}$ Edgar Thurston's Omens and Superstitions of Southern India, pp. 199 - 
Persons of riper age are kidnapped by wretches who trade in human flesh. The victim must always be purchased. Criminals, or prisoners captured in war, are not considered fitting subjects. The price is paid indifferently in brass utensils, cattle, or coin. The zanee [or priest], who may be of any caste, officiates at the sacrifice, but he performs the poojah [offering of flowers, incense, etc.] to the idol through the medium of the toomba, who must be a Khond child under seven years of age. This child is fed and clothed at the public expense, eats with no other person, and is subjected to no act deemed impure. For a month prior to the sacrifice, there is much feasting and intoxication, and dancing round the meriah, who is adorned with garlands, etc., and, on the day before the performance of the barbarous rite, is stupefied with toddy, and made to sit, or, if necessary, is bound at the bottom of a post bearing the effigy above described. The assembled multitude then dance around to music, and, addressing the earth, say 'Oh! God, we offer the sacrifice to you. Give us good crops, seasons, and health.' After which they address the victim. 'We bought you with a price, and did not seize you. Now we sacrifice you according to custom, and no sin rests with us.' On the following day, the victim being again intoxicated, and anointed with oil, each individual present touches the anointed part, and wipes the oil on his own head. All then proceed in procession around the village and its boundaries, preceded by music, bearing the victim on a pole, to the top of which is attached a tuft of peacock's feathers. On returning to the post, which is always placed near the village deity called Zakaree Pennu, and represented by three stones, near which the brass effigy in the shape of a peacock is buried, they kill a pig in sacrifice, and, having allowed the blood to flow into a pit prepared for the purpose, the victim who, if it has been found possible, has been previously made senseless from 
intoxication, is seized and thrown in the bloody mire amid the noise of instruments. The zanee then cuts a piece of flesh from the body, and buries it with ceremony near the effigy of the village idol, as an offering to the earth. All the rest afterwards go through the same form, and carry the bloody prize to their villages, where the same rites are performed, part being interred near the village idol, and little bits on the boundaries. The head and face remain untouched, and the bones, when bare, are buried with them in the pit. After this horrid ceremony has been completed, a buffalo calf is brought in front of the post, and, his forefeet having been cut off, is left there till the following day. Women, dressed in male attire, and armed as men, then drink, dance, and sing round the spot, the calf is killed and eaten, and the zanee is dismissed with a present of rice, and a hog or calf."

Col. Campbell' writes: "One of the most common ways of offering the sacrifice in Chinna Kimedi is to the effigy of an elephant (hatti mundo or elephant's head) rudely carved in wood, fixed on the top of a stout post, on which it is made to revolve. After the performance of the usual ceremonies, the intended victim is fastened to the proboscis of the elephant, and amidst the shouts and yells of the excited multitude of Khonds, is rapidly whirled round, when, at a given signal by the officiating zanee or priest, the crowd rush in, seize the meriah, and with their knives cut the flesh of the shrieking wretch so long as life remains. He is then cut down, the skeleton burnt, and the horried orgies are over. In several villages I counted as many as fourteen effigies of elephants, which had been used in former sacrifices. These I caused to be overthrown by the baggage elephants attached to my camp in the presence of the assembled Khonds, to show them 1864.

'Personal Narrative of Service among the Wild Tribes of Khondistan, 
that these venerated objects had no power against the living animal, and to remove all vestiges of their bloody superstition."

A hymn, sung during the passion of the victim, is preserved by Risley in The People of India, p. 62 (1908) which, reduced to a metric version, reads thus:

\footnotetext{
"As the tears stream from thine eyes,

So may rain in August pour;

As drips mucus from thy nose

So may drizzles sometimes come;

As thy blood is gushing forth,

So may vegetation sprout;

As thy gore falls down in drops,

So the grains of rice may form."
}

Col. Campbell also describes a meriah sacrifice of the Khonds of Jeypore:

"It is always succeeded by the sacrifice of three human beings, two to the sun in the east and west of the village, and one in the center, with the usual barbarities of the meriah. A stout wooden post about six feet long is firmly fixed in the ground, at the foot of it a narrow grave is dug, and to the top of the post the victim is firmly fastened by the long hair of his head. Four assistants hold his outstretched arms and legs, the body being suspended horizontally over the grave, with the face toward the earth. The officiating junna or priest, standing on the right side, repeats the following invocation, at intervals hacking with his sacrificing knife the back part of the shrieking victim's neck. 'Oh! mighty Manicksoro, this is your festal day. To the Khonds the offering is meriah, to the kings junna. On account of this sacrifice, you have given to kings kingdoms, guns and swords. The sacrifice we now offer you must eat, and we pray that our battle-axes may be converted into swords, our bows and arrows into gunpowder and balls; and, if we have any quarrels with other tribes, give us the victory. Preserve us from the tyranny of kings and their officers.' Then addressing the victim, 'That 
we may enjoy prosperity, we offer you as a sacrifice to our god Manicksoro, who will immediately eat you, so be not grieved at our slaying you. Your parents were aware, when we purchased you from them for sixty rupees, that we did so with iittent to sacrifice you. There is, therefore, no sin on our heads, but on your parents. After you are dead, we shall perform your obsequies.' The victim is then decapitated, the body thrown into the grave, and the head left suspended from the post till devoured by wild beasts. The knife remains fastened to the post till the three sacrifices have been performed, when it is removed with much ceremony."

When the cruel custom was officially abolished by the British government in 1852 , the Khonds demanded the privilege of sacrificing buffaloes, monkeys, goats or other animals as they had formerly sacrificed human victims. At the same time they insisted that they should be allowed to denounce in their prayers with impunity the government in general, and some of its servants in particular, as the guilty party for their deliquency in the performance of their religious duties which they considered both indispensable and sacred.

In spite of the seriousnesss with which the British government has stopped these barbaric rituals, the idea of the need and meritoriousness of human sacrifices still haunts the minds of the people, and there have been repeated occurrences which indicate that now and then sacrifices are still attempted or even actually take place, the vestiges of which are as much as possible concealed from the police.

We here quote the testimony of a case that was judged in the courts of the Bellary district in Igor. The man had offered his son as a sacrifice in the temple, but was apprehended by the police and imprisoned. The record of the Sessions Judge reads as follows: 
"The prisoner has made two long statements to the magistrate, in each of which he explains why he killed the child. From these statements it appears that he had been worshiping at the temple of Kona Irappa for six or seven years, and that, on one or more occasions, the god appeared to him, and said: 'I am much pleased with your worship. There is wealth under me. To whom else should it be given but you?' The god asked the prisoner to sacrifice sheep and buffaloes, and also said: 'Give your son's head. You know that a head should be given to the god who confers a boon. I shall raise up your son, and give you the wealth which is hidden under me.' At that time, the prisoner said to the god: 'I have only one son. How can I give him?' The god replied: 'A son will be born. Do not fear me. I shall revive the son, and give you wealth.' Within one year the deceased boy was born. This increased the prisoner's faith in the god, and it is apparent from his own statement that he has for some time past been contemplating human sacrifice. He was advised not to sacrifice the son, and for a time was satisfied with sacrificing a buffalo and goats, but, as a result, did not succeed in getting the wealth that he was anxious to secure. The prisoner says he dug up some portion of the temple, but the temple people did not let him dig further. The boy was killed on a Sunday, because the prisoner says that the god informed him that the human sacrifice should be on the child's birthday, which was a Sunday. The prisoner mentions in his statement how he took the child to the temple on the Sunday morning, and cut him with a sword. Having done so, he proceeded to worship, saying: 'I offered a head to the bestower of boons. Give boons, resuscitate my son, and show me wealth.' While the prisoner was worshiping the god, and waiting for the god to revive his son, the reddi (headman) and the police came to the temple and interrupted the worship. The prisoner 
believes that thereby the god was prevented from reviving the son.... The facts seem to be clear. The man's mind is sound in every respect but as regards this religious delusion. On that point it is unsound."

It would be difficult for a judge of India to regard a man who sacrifices his own son in any other light than as religiously insane, but we ought to bear in mind the parallel case of Abraham's intended sacrifice of Isaac as recorded in the Bible, Genesis xxii.

In reading the accounts of the stories of human sacrifices.which extend down to our present day, the significance of Christianity will be clearly seen in having once for all done away with the idea of human sacrifice, but we will point out that the abolition of human sacrifice has not been accomplished by a public declaration of the uselessness of such sacrifices, but by recognizing as it were the justice of the underlying idea, and by claiming that in Christianity this indispensable need of mankind in the interest of salvation through vicarious atonement has been fulfilled in the sacrificial death of Jesus on the cross, and we must remember that every mass represents symbolically the sacrificial offering of the host.

Death on the cross was originally an offering to the sun, and it is noteworthy that in the language of the Septuagint, the Greek version of the Old Testament, the word "to crucify" is translated exeliazein, which means "exposing to the sun." A sacrifice to the sun is either performed by burning the victim, "making it pass through the fire," which act is commonly called in Greek holocaust, i. e., a burning up of the whole; or it is done by crucifixion, i. e., by allowing the sun to suck out, as it were, the life of the victim. These sacrifices prevailed most among the Semites from whom the Romans adopted them, and it was a common belief that they were considered as most efficacious. Judging from ancient tradition, God could not 
refuse to grant fulfilment of a prayer if the the victim was a son of the supplicant.

In this sense we must read the passage in 2 Kings iii. 26-27, in which the king of Moab when hard pressed by the Israelites burned his eldest son, who was to have reigned in his stead, for a burnt offering upon the wall in full sight of the besieging enemy. After the sacrifice of the king's own son the Israelites abandoned the siege, despairing of taking the city.

According to the interpretation of two Roman Catholic archeologists $^{3}$ we must read a remarkable description of a sacrificial crucifixion in the history of Carthage in the same light as the story of the king of Moab who sacrificed his own son as a holocaust. The Roman historian Justinus tells us in his epitome of the Philippic histories of Trogus Pompeius that Maleus, a Carthaginian general, suffered a defeat and was exiled by the authorities of Carthage. He had been victorious and had sent the tenth of the booty home by his son Carthalo, who was thence despatched to offer it as a gift to the Tyrian Hercules at Tyre in Phenicia, the metropolis of Carthage. Indignant about the treatment Maleus had received at the hands of his compatriots, the Carthaginian general did not go into exile but returned home with the whole army to take revenge. While he was besieging the city, his son Carthalo returned from Tyre adorned with purple and priestly insignia. Having first attended to his religious duties in the temple, Carthalo met his father who bitterly reproached him for his lack of filial piety and had him crucified in his priestly robe on a high cross in sight of the besieged city. A few days afterwards he succeeded in conquering Carthage and took revenge on the authorities by having ten senators slain and himself reinstated. The triumph of the

- Von der Alm in Theologische Briefe, III, p. 138, and following him Dr. J. Stockbauer in Kunstgeschichte des Kreuses, p. 3. 
cruel father did not last long. Since he was suspected of striving for royal power the enemies of Maleus recovered their influence. They accused him of slaying his son and fighting against his country, whereupon he was condemned and executed.

Here we have another conspicuous instance of a human sacrifice, and if the interpretation of Von der Alm and Stockbauer may be trusted, we must assume that one who sacrifices his own son as an offering on the cross expects to attain the fulfilment of his wish from Baal.

There is no need of multiplying instances of a belief in the efficacy of a sacrifice of one's own son. They can be found in folklore all over the earth, and facts of a kindred nature have been gathered by Professor Frazer in his famous book The Golden Bough. We have the cruel rites of human sacrifices in ancient Mexico and in addition the wide spread custom of theophagy, the ceremonial eating of the god.

The most essential feature of life is the truth that the maintenance of life is a constant struggle and its end is death. The fittest survive, and the fittest are those who gain advantages through the love and sacrifice of their parents and fellow beings. We live through sacrifice, and through continued sacrifice the human race rises higher and higher. In this sense life is and will forever remain a tragedy. The climax of the struggle need not lead to actual death, but it must always involve suffering and tribulation; the main point is that tragedy means a victory through sacrifice.

In the light of this fact we can understand how Aristotle could see in a tragedy the most perfect expression of art, and also how religion from its most primitive stage up to the highest summit of its development should be a more and more refined presentation of a tragedy. 
The truth that life is a tragedy is a common occurrence in experience, and progress is made through sacrifice. This has been true for all times and is true to-day, but in former days when life was governed more by superstitious notions the tragic events were more dramatic, and this can be seen in countries which are not yet so far advanced as we are wont to see in modern European and American cities.

As an instance which fully expresses the meaning of this truth I will quote here an incident of modern Hindu life: It is well known that girls are considered a burden in India because the religious traditions of orthodox Hinduism demand that girls should be married at a definite age, and it has become an established custom that the bridegroom must be bought. This custom has been taken advantage of by ambitious youths who thus gained a means of acquiring a higher education. The educated youth having a chance of earning a better living is in high demand, and parents are compelled by religious usage to dispose of their daughters. The bridegrooms frequently stipulate not only the payment for their education but also further sustenance in the first years of married life to continue to complete their studies. This nuisance has contributed to the impoverishment of many families who in their religious fervor wished to comply with the requirements of their orthodox faith. It was for this reason that the infanticide of girl babies was practised in India, and it happened of late that a girl by the name of Snehalata ("the creeper of affection") was to be married to a bridegroom for whom the parents-in-law had to pay a price of 1800 rupees, and 1200 rupees worth of jewels. These expenses were too hard on the family, and in order to free her parents from the crushing debt involved by her marriage the girl decided to sacrifice herself for the benefit of the family. She burned herself to death and the touching letter which she left behind reads as follows (see Open Court, July I9I4): 
"Father, I have heard that many noble-hearted and educated young men volunteered for philanthropic work for the relief of the sufferers from the Burdwan floods. God bless their kindly hearts, so full of compassion for their suffering fellow-beings. I have also heard that many young men have taken a vow not to buy bideshi (foreign) articles. Only the other day I heard how bands of nobleminded youths had gone from door to door to raise funds for the relief of some people in far away South Africa. But is there no one among them to feel for their own people?

"Last night I dreamt a dream, father, which made me take my vow. To the enthralling strains of a music unheard before, and amid a blaze of light as never was on land or sea, I saw the Divine Mother Durga, with benignant smile, beckoning me to the abode of the blest, up above, and then I thought of you father, of the ever sorrow-laden face of my beloved mother and of the dear little ones who have done so much to brighten our home. And then I resolved to save you all and made a sign to the Divine Mother that I would not delay obeying her merciful call.

"After I am gone, father, I know you will shed tears over my ashes. I shall be gone-but the house will be saved. Since then I have been pondering on the best way of ending my worldly pilgrimage-fire, water, or poison. I have preferred the first, and may the conflagration I shall kindle set the whole country on fire!"

The event has stirred India and the movement started through the excitement has produced among other good results the foundation of a society of Indian youths who take the vow not to accept any "bridegroom price" on account of their marriage. Here is a glaring instance of a sacrifice done for a purpose, a sacrifice which is sure to 
bring good results, and little Snehalata is worthy to be mentioned among the heroes and martyrs of mankind."

The Christ-conception existed before Christ and has had its influence on the dogmatic interpretation of the life of Jesus. Whether or not Jesus was a historical person is a question of passing interest, for the superpersonal figure of the Christ ideal is the founder of Christianity, not St. Paul nor Jesus the Nazarene; and it is certainly not a mere accident that we do not speak of Jesuanity but of Christianity.

In comment on the theory of the non-historicity of Jesus, so doughtily advanced by Prof. William Benjamin Smith of Tulane University, and again championed in the present number of The Monist by $\mathrm{Mr}$. K. C. Anderson (who, however, strange to say, makes no reference to him) we wish to say that we can not be convinced of the negative aspect of their views, the non-existence of Jesus, although we fully accept the positive claim that Christ, not Jesus, is the formative factor of Christianity.

In connection with a discussion of the Christ problem, a few comments will be in order on Mr. Kampmeier's article "Are We Just to Jesus?" which is published in the current number of The Monist, and we must say in justice to the author and in explanation of the motive that instigated him to treat this subject, that the article is practically a criticism of my own view upheld in editorials. In a personal letter to Mr. Kampmeier, I descanted on the proposition that for any essential questions, and also for practical purposes, it was quite indifferent whether or not Jesus had lived or of what character he may have been.

Christianity originated through syncretism. The ideal of Christ existed before Jesus, and it is the ideal of Christ and not Jesus that has become the founder of Christianity.

- Incidentally I wish to call attention to the story of The Chief's Daughter, describing the last sacrifice of the Niagara Indians, and treating the subject in this spirit (Open Court Publishing Co., 1901). 
Ideals (i. e., superpersonalities) need not be historical persons. They are heroes or gods and their efficiency is greater than historical persons. It is probable that Dr. William Benjamin Smith means in his proposition that Jesus is a god, and only a god, not a man, the same as we mean by a superpersonality.

The main portion of my letter to Mr. Kampmeier criticized by him in his article contains the following expositions:

First of all I recognize plainly that the Gospel stories of Jesus contain much material which is not of a historical origin. We find in them traces of sun myths; incidents of the lives of previous saviours have been superadded upon Jesus; ideas of a Christ which were prevalent at the time, have been introduced as historical facts; finally sayings attributed to former saviours or Buddhas are ascribed to Jesus, and so we find innumerable references to parallel formations in other religions. All these items have been used as evidence to prove the non-historicity of Jesus. What they really prove is that an ideal was prevalent among the nations which we may call the ideal of a Christ, a Messiah, a Buddha, a Mithras, a Jaina, a god-man, a divine incarnation, etc. I have no doubt that books existed which contained the sayings of a divine teacher, and they were derived most likely from Indian sources, containing many Buddhistic ideas. Such must have been the book used in the synoptics, called " $Q$ " by Wellhausen.

The idea that Christ was not historical seems to suggest itself, but there are remnants left which do not agree with this Christ-ideal, and stand even in contradiction to the traditional notion of the Greek Christ-ideal as it prevailed among the Gentile Christians. These little remnants of an Aramaic personality indicate that there is an element in the Gospels which has little to do with the Christ-ideal, and 
seems to be the underlying and historical root upon which all the rest has been grafted.

In the synoptic Gospels Jesus is a healer. Apparently he made a living by healing. He is a fanatic in his way, and certainly not the gentle Jesus of the Unitarians, the liberals among the higher critics, or the historicists. $\mathrm{He}$ could curse a fig-tree simply because it did not bear fruit when he wanted a fig, and that when the time of figs was not yet. The Jesus of Mark let loose a legion of demons in Gadara where they hurled a herd of swine into the sea. He could curse his adversaries, the scribes and Pharisees, in a sweeping and wholesale condemnation. Even granting that most of the scribes and Pharisees were hypocrites, we need not doubt that there were among them many pious people; but they were as much his enemies as the physicians are the enemies of mind-cure healers and Christian scientists to-day. He, the traveling healer, interfered with their profession of supervising the hygienic conditions of the people and their business of pronouncing on the health of lepers, etc.

Moreover this historical Jesus must have been a Jew of the narrowest kind, for he called the Gentiles dogs,an expression in Matthew xv. 26, smoothed down, probably by a Gentile copyist's hand, to "lap dogs" or "little dogs," a pet name, not "dogs." $\mathrm{He}$ also declared in Matthew v. I8 that "Till heaven and earth pass, one jot or one tittle shall in no wise pass" from the Mosaic law."

The passage which mentions the brothers and sisters of Jesus ${ }^{8}$ can only by very artificial means be interpreted as

\footnotetext{
- kuvaplois.

"kvolv. Compare Matt. vii. 6, where "dogs" can only refer to the Gentiles.

That must have been the original meaning of this well-known contradictory passage. The second clause "till all be fulfilled" is apparently a later addition. The Mosaic law had been abolished because (as St. Paul argued) it had been fulfilled.

- Mark iii. 31-35.
} 
having a symbolic meaning. Here we have scriptural evidence of his family, and we have reason to believe that he did not live in concord with his mother and his brothers and sisters, for he refused to see them.

There are further indications of a concrete background not in accord with Gentile tradition, and I will mention a few of them. The existence of Nazareth seems doubtful. There is a confusion between Nazaree, the member of a sect, and Nazarean, meaning the man from Nazareth. The early Christians and St. Paul are called Nazarenes, although they were not born in Nazareth. The argument that Nazareth as a town does not make its appearance before the fourth century is well known, and it is more than probable that the home of Jesus was Capernaum. At any rate Capernaum was called "his city."

The apostle Paul never met Jesus, but he knew his brother James and other disciples, especially Simon, called Cephas or Peter. Why should the expression "brother" be symbolical as Dr. Smith claims? There is no probability that the quarrels between Peter and Paul should be later inventions of a symbolical nature, for we must bear in mind that the pact between Peter and Paul to divide the world between them makes the story of Peter's journey to Rome and his becoming the first bishop of Rome, if historical, a palpable breach of faith.

The life of Jesus was apparently passed in the province of Galilee, and if we ignore the story of his visit to the temple in his childhood, he seems to have come to Jerusalem only once when he was seized and crucified.

All his sayings give not the slightest indication that he busied himself with the political problem of his people. $\mathrm{He}$ thinks of their immediate ailments and diseases. The passage concerning Cæsar's imprint on the coins does not make the impression of being a historical incident. It was probably a later invention to make Christianity acceptable 
to the Roman government, for the meaning of the incident seems to characterize the later situation.

It stands to reason that when Jesus came to Jerusalem he offended on both sides, the priests or orthodox Jews who never cared much for Galileans, and the Romans who naturally would see in him a dangerous rebel.

According to tradition in Mark Jesus was very impulsive, and possibly a fanatic Nazarene sectarian. If the Nazarenes were actually the same sect as the Essenes, he must have been opposed to bloody sacrifices and this would explain his wrath when entering the temple. Did his words perhaps imply an objection to the slaughter of animals when he said: "Is it not written, My house shall be called the house of prayer? but ye have made it a den of thieves?"

The original" here means "a den of robbers or pirates or buccaneers," viz., men who kill to rob. Luther translates Mördergrube. If Luther's version is correct the story acquires a definite meaning and the narrative of the purging of the temple may be based upon an actual occurrence, which would naturally make many enemies, not only among the venders of doves themselves, and the money changers and the orthodox Jews, but also among all those common people who were in business contact with the traders at the temple gate.

The stories of the crucifixion are apparently modified through the principle not to cast any blame on the Roman authorities. There was a time when Christianity endeavored to ingratiate itself with Rome. Paul prides himself on being a Roman citizen and finally Roman Christianity against the faiths of the Armenians and Copts became its orthodox form. Yet it is clear that Jesus was not crucified by the Jews upon whom the opprobrium of the deed is thrown, but by the Romans, and so Pilate is represented as a weak man who became a mere instrument in the hands

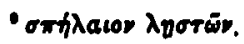


of the highpriests. Yet we ought to take note that Pilate had no right to sit in judgment in Jerusalem. Jerusalem stood under the jurisdiction of Herod, except perhaps, as probably was the case at the time of feast, when martial law was pronounced.

The prophecy that people standing by would live to see Jesus come in the heavens with all his glory is an irrefutable proof that the passage is old and genuine. ${ }^{10}$ It must have been written in the first century, and has not been removed as unfulfilled. It is another indication that the Gospels contain at least a nucleus of genuine old traditions.

Thus I base my views of the historicity of Jesus mainly on those passages which would not have been written if Jesus had been a mere ideal figure constructed for the sake of symbolization or as an incorporation of an old sun myth, or a new formation of a divinity of some kind or a belief in a saviour-god, or a Yahveh cult, or a kind of Judaized Buddhism. The original documents must have been based on genuine records of a real man, although the essentially Christian elements (viz., those narratives which are typical of saviour stories) as well as the sayings of a religious sage, the parables, the Lord's prayer, the beatitudes, the Logia in the " $Q$ " document, etc., may have been superadded in the course of the development of the New Testament scriptures.

While I believe that Christianity has been called rightly after Christ and not after Jesus, $\mathrm{Mr}$. Kampmeier recognizes Jesus as the founder of Christianity and thinks that the church would not have originated without the man Jesus. But the New Testament itself furnishes the evidence that it was St. Paul who identified the two. We read in the Acts (xviii. 24) that there was a teacher called

\footnotetext{
${ }^{10}$ The same argument has been used by Schopenhauer and is likewise considered irrefutable by Garbe. See his article in the present number.
} 
Apollos who "taught diligently the things of the Lord," which is the typical expression for the Christ, the religious ideal of the God-man whom the Jews called Messiah and the Gentiles the Saviour. ${ }^{11}$ Apollos was perfectly familiar with the Christ-ideal, but he had never heard of Jesus, and the Gospel which Paul preached consised in this, that this Christ had become flesh in Jesus, and Paul succeeded in having Jesus recognized as the Christ. In this sense and in this alone Paul may be regarded as the founder of Christianity.

Why Jesus was better than any other figure to be identified with the highest religious ideal of the age need not be discussed here. We must assume that the humanity of Jesus and his martyr's death were more sympathetic to the down-trodden multitudes of the Roman empire than the more philosophical figure of Apollonius of Tyana and the mythological personality of a Mithras. But we claim that some other figure might have taken the place of Jesus, in which case the narratives of a saviour, of an ideal teacher, of a healer, of a conqueror of death, etc., would have crystallized about this other person in the same way as in the development of Christianity they have crystallized around Jesus.

This view is naturally regarded by men like $\mathrm{Mr}$. Kampmeier as an underestimation of Jesus, and so he has felt called upon to explain his position and give his answer to the question "Are we just to Jesus?" His opinion represents an important phase in the conception of the Christideal most prevalent among the Unitarians and other liberal Christians, and so we feel that in order to complete the discussion of the Christ-ideal his view should not be overlooked.

While we believe that the Christ-ideal, the superperHebrew.

12 The term owrtp is Greek, not Jewish; the very word does not exist in 
sonality of a saviour and not the human personality of Jesus, has made Christianity and has always remained its backbone, we see no necessity of denying the historicity of Jesus. Occam's razor, as Prof. W. B. Smith argues, can no more cut it off than M. Pérès's ingenious proposition of the Apollo incarnation of Napoleon will render Buonaparte unhistorical or as the poem of the Alexander myth will change Alexander the Great into a mere solar hero. The amalgamation of myth and history is too common to see in it anything improbable or even impossible.

I wish to add one suggestion which may be helpful for the interpretation of the facts of our religious development. Superpersonalities, such as ideals, gods and religious aspirations; heroes, such as Heracles in ancient Greece; also the figures of great men (not what they were in life but what became of them after death) such as Bismarck, Washington, Napoleon, etc., are not nonentities, but important factors in the life of mankind. The thought of Heracles was not a mere fable to the Greek youth but a potent influence which moulded his life, and so the Christconception of to-day is and has been since the beginning of the Christian era, a living power in the Christian churches. We must learn to appreciate the superpersonalities of secular life as well as of the gods of pagan religions by recognizing the paramount influence which such ideals exert in the life of the people. ${ }^{12}$ This is true of Christ and also of the analogous pagan notions, although we now find difficulty in appreciating their significance. Only if we compare pagan sentiments to the sentiments which Christians entertain for Christian beliefs, shall we catch glimpses of the truth.

We see a lesson in the struggle for the historicity or non-historicity of Jesus, which is this. The liberal party

"Concerning the nature of "superpersonalities" see the writer's little book Personality With Special Reference to Superpersonalities and the Interpersonal Character of Ideas, Chicago, 1911. 
of theology has succeeded in breaking down the claims of the old orthodoxy, but the liberals have gone too far. In attacking the letter of dogma and tradition they have denied the spirit. As a rule they do not understand the meaning of the religion whose beliefs they attack. So it is natural that they see in Jesus a mere man; they deny his divinity. All their hope is therefore set in the human Jesus. Jesus has been stripped of all supernatural qualities, he remains to them a mere man. $\mathrm{He}$ is good, indeed very good. $\mathrm{He}$ is a paragon of virtue, a veritable model of Sunday-school morality, and this is expressed by calling him "the gentle Jesus" or honoring him with similar names. $\mathrm{He}$ is not a God, not a superpersonality, but an ideal man, and he is assumed to be the founder of the church. The orthodox position is rejected as irrational, impossible and superstitious. To these liberals it is sufficient to prove the Christ figure to be mythological.

Now we will unreservedly grant that Christ is a mythological figure; and all that the Mediterranean people ascribed to a saviour-the virgin birth, the power to perform miracles, a blameless character, the fate of martyrdom, of suffering and dying for others, the resurrection from the tomb and an apotheosis in one form or another, all the wisdom of the ages-was attributed to him as a matter of course. Such is the logic of a religious mind. This is the way in which a believer argues. It is founded in the constitution of a man's being that a saviour must have sacrificed himself for the good of mankind, therefore Christ's death was an act of vicarious atonement.

Here is an instance of how the scriptures grew by accretion: A Christian hears that when Socrates died he forgave his enemies. A pagan may have argued, "You see Socrates was nobler than Christ." But the Christian thinks: "Christ was the ideal man, therefore he can not have been outdone by Socrates; he too must have forgiven 
his enemies." The passage in Luke xxiii. 34 does not occur in the oldest manuscripts but was inserted comparatively late by a copyist who was somehow familiar with Plato's Crito and had adopted this typically human argument. Once inserted, the passage remained a most highly appreciated verse in the gospel story, though no critical student of the New Testament will venture to regard it as historical.

We read of Zarathustra and of Bodhisattva that they were tempted by the Evil Spirit before they started on their careers. Great moral teachers must first have proved that they knew the nature of evil and that they could overcome the tempter. Therefore Jesus must have been tempted.

We need not increase instances to explain how ideals grow and how they naturally develop by incorporating what is kin to them and assimilating what by slight changes can be adapted. And ideals are predetermined in the constitution of being like Platonic ideals, like the types of the several atoms, like the chemical compounds, predetermined in their nature, and also like plants and animals and rational beings. We are sure that the atoms of gold are the same on earth as in the sun and in the stars of distant worlds. So we can be sure that the same law will develop similar organisms in the most distant planets, and the moral leaders of a group of rational creatures will teach the same ethics of universal good-will as all the abstract thinkers will invent the same geometry however different may be their roads of approach or methods of demonstration or schemes of explanation. So the ideal of a Christ is not only predetermined by the history of the people where the story of a saviour grows, but is also founded, at least in general outlines, in the conditions of the social life of rational beings. Thus a Christ can rightly 
say: "Before Abraham was I am." In fact the ideal man, as an ideal, existed in the beginning of the world and it was with God. It is as eternal as God and is the divine factor which determines the development of life toward the realization of the Christ ideal.

We see that the orthodox view contains a truth which no higher criticism can kill. The construction of an ideal man, such as the gentle Jesus of liberal theology will scarcely be verified by historical investigation, and in our opinion it is quite indifferent for us to-day what Jesus thought and did and whether he was as gentle as described in Unitarian tractates or whether he was as zealous and stern as the Jesus according to Mark who expels demons, commands the storm and allows a herd of two thousand swine to drown, forbids his disciples to approach the Gentiles and the Samaritans, consigns Dives to hell, requires the rich youth to sell all he has and give to the poor, curses the fig-tree, scourges the money changers from the temple gates, expels other poor venders peddling pigeons etc. If we want to render the Gospel story useful for us to-day, we must reinterpret it in the spirit of to-day and must explain the incidents of the life of Jesus in the light of the Christ-ideal which we have to-day.

One thing seems assured. The Christ-ideal of the church is not the Jewish Messianic ideal. It is the ideal of a healer like Esculapius, who cures the blind and makes the lame walk again; of a teacher of ethics such as taught in the school of neo-Platonism; of a preacher such as could be found among the Stoics. Moreover this ideal was a godman. As Hercules found comfort in the idea that he was the son of Zeus, so Jesus addressed God as his father.

Such is the Jesus of the latest Gospel according to St. John which though it may have incorporated older elements is the least historical and ranges highest in significance. Had it not been written Christianity might not 
have overcome its rival religions, Gnosticism, Manicheism, Mithraism or even the belief in Apollonius of Tyana. The main factor, however, which gave strength to Christianity lies in its recognition of life as suffering, and the conquest of evil by sacrifice.

On a superficial inspection life seems a joyful display of energy, a kind of frolic entered into for the fun of it. Such is naturally the opinion of childhood and youth, but mature manhood with its struggles and cares will soon enough teach us the earnestness of life. The time will come to every one who reaches maturity of thought, when he will understand that life is a tragedy, and this lies in the very nature of thought.

Every heroism procuring reform or progress means a sacrifice of the present for the future, of the generation of to-day for the generation to come, of the life-blood of the parents for the welfare of their children, yea of the present hour for the years to come.

This is true generally, but it is specially true of the heroes of mankind who bear the brunt of the battle for progress, and so it is but natural that the quintessence of all the religions that can claim any depth of conception deal with the problem of evil and teach us to face and to overcome the tragic element in life. The North American Indian wanted to show to the Great Spirit what suffering his sons could endure and so underwent the horrible tortures of the sun dance. The Syrian Adonis, the lord, or Tamuz, personified vegetation, and his devotees witnessed his tragic death in religious mysteries. Similar ideas pervade almost all the pagan religions, and the gist of Christianity is this same world-old tale of the god who offers himself up for the best of mankind, who dies on the cross that those who believe in him may gain life everlasting.

These considerations explain Christianity as the re- 
ligion of mankind and also the similarity of Christianity to the pre-Christian Gentile religions. ${ }^{13}$

Mankind wants and indeed needs a religion that sets forth the truth of tragedy, of our struggle with the power of evil, and of triumph over evil through sacrifice. If we understand the history of religion aright and if we study the data of comparative religion with sympathy-or, if that be grudged to pagans, merely with justice-we shall be able to trace the common basis of all faiths in the crucial truth that all life is a tragedy, and this remains true whether or not there are historical connections between the pre-Christian and Christian institutions, such as Lenten ceremonies and Easter festivals.

The recognition of this idea will remove many misgivings in the circles of those theologians whom Christ addresses with the words "Ye of little faith" and we are glad to notice that some scholars begin to understand the significance of this conception. We quote from Dr. Hugo Radau's Sumerian Hymns and Prayers to God Dumu-zi or Babylonian Lenten Songs, ${ }^{14}$ (Preface, pp. vii-viii):

"Strange indeed and most remarkable are the parallels between the Sumerian and Christian Lenten and Easter festivals :

"Dumuzi goes to the 'north' or 'netherworld,' i. e., he 'dies,' in order to conquer the 'enemy from the north,' the cold, winter, darkness. Christ dies in order to conquer Satan, the 'prince of darkness.'

"Dumuzi while in the netherworld is 'bewailed' by his 'Bride' Ishtar, especially during the month FebruaryMarch (Ululu) ; but this is exactly the season of the Chris-

w This idea is outlined in a little book entitled The Pleroma (Open Court Publishing Co., 1909) which is a historical account of the pre-Christian struggle for religious supremacy, and how it resulted in Christianity as the fulfilment-the pleroma-of the needs of the times.

"Published as Vol. XXX, Part I, of The Babylonian Expedition of the University of Pentrsylvania, Munich 1913, to be obtained through Rudolf Merkel, Erlangen, Germany. 
tian Lent, during which the church, the 'Bride of the Lamb,' mourns over the death of her 'bridegroom,' Christ.

"The month Ululu is followed immediately by the 'month of the festival of Dumuzi' which begins with the vernal equinox and which celebrates, among other things, Dumuzi's marriage with 'Mother Earth,' the resurrection of nature and the beginning of new life. The Christian lenten season is terminated by the Easter festival, celebrating at the time of the vernal equinox the resurrection of Christ and the beginning of a new, spiritual life (zoopoietheis de to pneumati, I Peter iii. I8) of Christ and of his church, thus demonstrating, corroborating and proving the truthfulness and correctness of the Sumerian resurrection festival, for 'if there is no resurrection of the dead, neither hath Christ been raised' or again 'if the dead are not raised, neither hath Christ been raised' ( $\mathrm{I}$ Cor. xv, I $2 \mathrm{ff}$ ).

"The Christian lenten and resurrection festivals are in this wise by no means merely a 'rehash' of Babylonian ideas. This would be misunderstanding the divine will as carried out in history. No, not a 'rehash,' but the very culmination and 'fulfilment' of the wisdom of ages past are the Christian lenten and resurrection festivals. The 'truth' which the Sumerians dimly recognized while still groping in the dark receives by the death and resurrection of Christ its true light, explanation, seal, approval and spiritual significance. Christ and the Christian religion not only is, but must and, I am sure, will be recognized, more and more, to be what we are told it is: the pleroma.

"In thus admitting, on the one hand, the exact parallels between the Sumerian and the Christian lent and resurrection, and on the other recognizing in the Christian festivals the pleroma of their predecessors among the Sumerians, we will not stand in any danger of losing our faithon the contrary, the Christian religion will become for us 
a living reality, the last link in the long chain of divine revelations uniting us with the past and into a common brotherhood of man, believing the same thing and hoping for the same thing: our own resurrection.

"Let us, therefore, be true to ourselves and recognize the divine element even in the Sumerian religion, at the same time let us not forget that grand and sublime though the Sumerian religion may be, it is but a faint shadow of the light that shines in Christ. This 'declaration of faith' I am constrained to make publicly here in response to several communications and criticisms from certain quarters requesting me to state frankly and honestly my position and personal belief with regard to the Sumerian religion in its relation to that of the Christians."

Here is our conclusion: The tragedy of Golgotha is the most characteristic and the most essential trait of Christianity, and still to-day we recognize the truth that every enhancement of life, every progress, the widening of our horizon in politics, in social life, in the discovery of truth, even in industrial enterprises, yea the mere maintenance of life and its continuance in the future generation, the rearing of children and their education can be accomplished only through sacrifices. Life is a constant struggle: we fight and bear the brunt of the battle, we are perhaps wounded; we break down under the burden of toil and if the cause for which we fight be victorious, others, not we, will see the day of triumph; we pass away but mankind marches on. Such is the nature of the tragedy, such is the meaning of Christianity and such is the destiny of mankind.

EDITOR. 